\title{
Sete exercícios de escrita a partir do vazio
}

\section{Prisca Agustoni}

poeta, tradutora, professora associada de literatura comparada na Universidade Federal de Juiz de Fora (Brasil)

- priscapoeta@gmail.com

Dol https://doi.org/10.34913/ journals/lingualugar.2020.e426
Esses poemas-ensaios foram escritos a partir do estudo das obras de Mira Schendel e, em particular, de sua tentativa, levada adiante por ela ao longo da vida, de "surpreender a palavra no momento da sua origem".

Os poemas fazem parte de um conjunto maior, em fase de composição.

Les poèmes suivants ont été écrits à partir de l'étude des œuvres de Mira Schendel et, en particulier, de sa tentative, poursuivie tout au long de sa vie, de "surprendre la parole au moment de son origine".

Ces poèmes font partie d'une collection plus vaste, en cours de composition. 
1.

escrever

: exercício contra a eternidade:

o que pode o poeta

para fixar o movimento

da matéria?

ter entre as mãos

um sismógrafo que mede

o pensamento

e detecta

as ondas do silêncio,

a magnitude do gesto

[e das palavras

anteriores ao gesto

gravando na folha o traçado

das batidas do coração

- epicentro daquilo que pulsa

[e se desgasta:

escrever

: exercício de emudecer

a memória

despida da história 
2.

agora:

imagine a página

uma galáxia

oblíqua,

radiante:

as quatro faces da palavra

-estrela

ardem

em seu quadrante

(esfera azul

à deriva no branco)

língua-trêmula no vazio

da folha

gesto úmido do olho

que gira e capta

a libélula no ar,

sem o moto-contínuo

frenético

de suas asas 
3.

esse repetido ensaio

de margear o silêncio:

tentar dizer do pássaro

a sombra

da palavra, seu duplo

- o fantasma

4.

isto

isto é

isto é o mundo

vasto, isto é o mundo vasto

mundo,

mudo

visto

através do vazio

-cintilante

e lúcido -

do signo

- o olho

do poema:

: balbucio 
5.

Júpiter é dez vezes maior que a terra

diz o filho que agora sabe ler

penso o vazio

a concretude do vazio

penso o poema

a concretude do poema

como um baú de assinaturas,

cifras de um mundo

em devir

$$
\begin{aligned}
& \text { minha língua migra } \\
& \text { seta } \\
& \text { que gira }
\end{aligned}
$$

raios de um sentido

que sempre escapa;

penso o filho

sua desmedida noção

do abismo

o que somos,

o que podemos

apenas com um alfabeto

contra a órbita do tempo 
6.

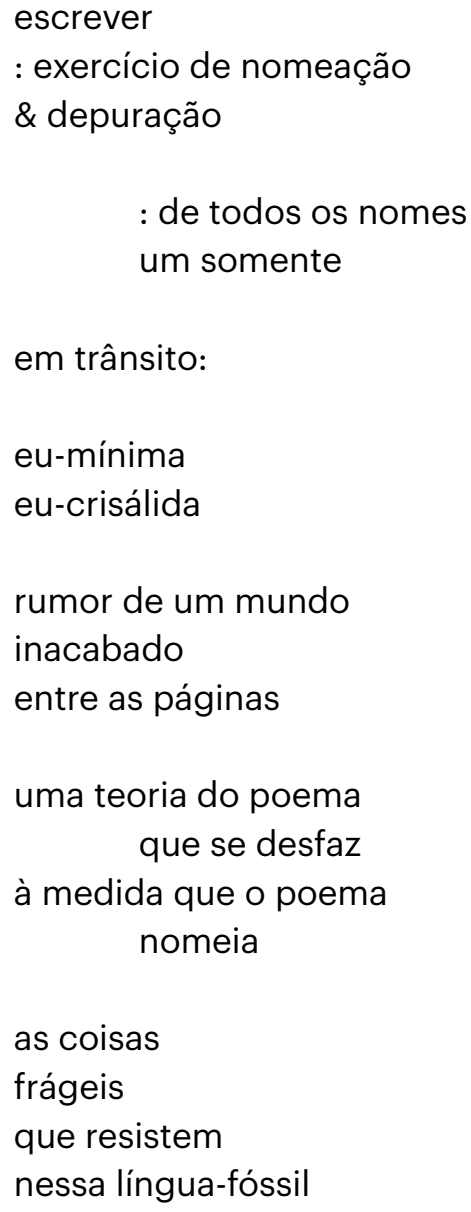

